\title{
Factors associated with blooms of cyanobacteria in a large shallow lake, China
}

\author{
Di Li ${ }^{1,2}$, Naicheng Wu ${ }^{3}$, Song Tang ${ }^{4}$, Guanyong Su${ }^{5}$, Xuwen $\mathrm{Li}^{2}$, Yong Zhang ${ }^{2}$, Guoxiang Wang ${ }^{6}$, Junyi Zhang ${ }^{7}$, \\ Hongling Liu', Markus Hecker ${ }^{8,9}$, John P. Giesy ${ }^{1,10,11,12}$ and Hongxia Yu ${ }^{1 *}$
}

\begin{abstract}
Background: Eutrophication of freshwater systems can result in blooms of phytoplankton, in many cases cyanobacteria. This can lead to shifts in structure and functions of phytoplankton communities adversely affecting the quality of drinking water sources, which in turn impairs public health. Relationships between structures of phytoplankton communities and concentrations of the toxicant, microcystin-leucine-arginine (MC-LR), have not been well examined in large shallow lakes. The present study investigated phytoplankton communities at seven locations from January to December of 2015 in Tai Lake, and relationships between structures and diversities of phytoplankton communities and water quality parameters, including concentrations of MC-LR and metals, were analyzed.

Results: A total of 124 taxa of phytoplankton were observed, and the predominant taxa were Microcystis sp. and Dolichospermum flos-aquae of Cyanophyta and Planctonema sp. of Chlorophyta. The greatest diversities of phytoplankton communities, as indicated by species richness, Simpson, Shannon-Wiener, the Berger and Parker, and the Pielou evenness indices, were observed in spring. Furthermore, productivity of phytoplankton was significantly and negatively correlated with diversities. These results demonstrated that Simpson, Shannon-Wiener, the Berger and Parker, and the Pielou evenness indices of phytoplankton communities were significantly related to trophic status and overall primary productivity in Tai Lake. In addition, temperature of surface water, $\mathrm{pH}$, permanganate index, biochemical oxygen demand, total phosphorus, arsenic, total nitrogen/total phosphorous ratio, and MC-LR were the main factors associated with structures of phytoplankton communities in Tai Lake.

Conclusion: The present study provided helpful information on phytoplankton community structure and diversity in Tai Lake from January to December of 2015. Our findings demonstrated that Simpson, Shannon-Wiener, the Berger and Parker, and the Pielou evenness indices could be used to assess and monitor for status and trends in water quality of Tai Lake. In addition, MC-LR was one of the main factors associated with structures of phytoplankton communities in Tai Lake. The findings may help to address important ecological questions about the impact of a changing environment on biodiversity of lake ecosystems and the control of algae bloom. Further studies are needed to explore the relationship between MC-LR and phytoplankton communities in the laboratory.
\end{abstract}

Keywords: Eutrophication, Nutrients, Phosphorus, Nitrogen, Phytoplankton productivity, Diversity, Microcystin-LR

\footnotetext{
*Correspondence: yuhx@nju.edu.cn

1 State Key Laboratory of Pollution Control and Resource Reuse, School of the Environment, Nanjing University, Nanjing, Jiangsu 210046, China Full list of author information is available at the end of the article
} 


\section{Background}

Biodiversity represents the complexity of life and includes phenotypic, genotypic, taxonomic and ecological diversity [1]. Characterization of biodiversity of phytoplankton communities can help managers and researchers understand the status and trends in changes in the structure of ecosystems, e.g., due to stressors such as contamination with pollutants and nutrients [2]. Therefore, understanding the ecological processes, as well as abiotic and biotic factors that contribute to absolute and relative abundances of taxa in these communities are major goals of basic and applied community ecology. Metrics, such as species richness and the Shannon-Wiener diversity index, represent important tools for the characterization of changes in phytoplankton communities in aquatic ecosystems [3-5].

Compositions of phytoplankton communities are crucial determinants of structures of food webs in aquatic ecosystems, and because of their rapid responses to environmental stressors such as pollution these are considered to be important environmental indicators [6-9]. Results of previous studies have suggested that water temperature (WT), water level, seasonality, optical properties, and nutrients, especially nitrogen $(\mathrm{N})$ and phosphorus (P) are the main factors that affect the composition of phytoplankton communities [9-15]. Hydrodynamic force, mixing depth, and euphotic depth were also important physical factors that influenced phytoplankton dynamics and bloom condition $[16,17]$. Species compositions and richness of phytoplankton can also be altered by exposure to pollution, such as metals $[18,19]$. Thus, to protect biodiversity and restore aquatic ecosystems, there is a need for regular monitoring to ascertain that these water quality parameters are within acceptable levels, and it is important to understand the impact of the changing environment on the structure of phytoplankton communities. Although productivity of phytoplankton, expressed as concentrations of Chlorophyll $a$, has been suggested as a robust indicator for assessment of quality of ecosystems [20], relationships between productivity and composition and diversity of phytoplankton have been seldom studied in aquatic ecosystems.

Due to human activities and climate changes, eutrophication of lakes have been global problems, and can cause significant shifts in phytoplankton communities resulting over-dominance of unwanted taxa, such as cyanobacteria [21]. Cyanobacteria blooms are expected to become more frequent, of greater severity and duration worldwide [22], posing serious threats to the health of many surface water ecosystems, and as such affecting the safety of drinking water sources [23]. Because of their unique characteristics, such as adapting low or high light, in the presence of excess nutrients, cyanobacteria have competitive advantages of many other species of plankton. Several cyanobacteria, such as Microcystis spp., Dolichospermum flos-aquae, and Oscillatoria tenuis, can produce toxins [24, 25], such as microcystins (MCs) [26], microcystins, especially microcystin-LR (MC-LR; L for leucine and $\mathrm{R}$ for arginine), are widely distributed across eutrophic freshwater ecosystems and have been shown to be toxic to a wide range of aquatic organisms and humans [27-31]. However, the impacts of MC-LR on structure and diversity of aquatic communities specifically phytoplankton communities have been rarely reported in natural waters [5, 32].

As the third-largest lake in China, Tai Lake is a shallow lake that is a critical source of drinking water for several populous cities of China. However, due to numerous anthropogenic stressors, between 1998 and 2007, a number of blooms of cyanobacteria occurred throughout the year, except for January and February [33]. Between 2008 and 2011, the frequency of algae blooms was increasing, and blooms occurred even in January [34]. Blooms of cyanobacteria first appeared in Meiliang Bay of Tai Lake in the 1980s [35], and previous studies found that absolute and relative density of phytoplankton in Tai lake was highest in this bay [36-38]. However, phytoplankton in the other areas of Tai Lake was seldom surveyed. In addition, since the most common freshwater cyanobacterium, Microcystis spp. [39], is also a dominating and problematic species in Tai Lake, this species has been extensively researched [40-42]. However, effects of the dominant taxa on the other taxa of phytoplankton during cyanobacteria blooms were seldom studied in the lake.

In the present study, variations in environmental conditions and communities of phytoplankton were investigated monthly at seven different locations of Tai Lake in 2015. The aims of this study were to (1) explore potential effects of environmental parameters on the structures of phytoplankton communities; (2) determine relationships between phytoplankton productivity and diversity: and (3) identify factors driving changes in dominant taxa of phytoplankton. Addressing these important ecological questions could help managers better understand biodiversity of plankton community and better make decision to protect this important shallow lake.

\section{Methods \\ Study area}

Tai Lake is located between Jiangsu and Zhejiang Province. Communities of phytoplankton were investigated monthly at seven different sites, which are two of the most densely populated regions in China. Tai Lake has an area of $2338 \mathrm{~km}^{2}$, with a maximum length and width of 68.5 and $56 \mathrm{~km}$, respectively. The average depth is approximately $1.9 \mathrm{~m}$ and the average annual air 
temperature is between 16.0 and $18.0{ }^{\circ} \mathrm{C}$. The annual mean precipitation is between 1100 and $1150 \mathrm{~mm}$. In the present study, seven sampling locations were established in Tai Lake (Fig. 1), which represented areas of differing ecological characteristics across the entire Lake. Specifically, they were in the eastern bay (TH1), Meiliang Bay (TH2), southwest area of the lake (TH3), northwest area of the lake (TH4), central lake (TH5), and Gonghu Bay (TH6 and TH7).

\section{Sampling}

\section{Collection of water and analyses}

Sampling was performed at seven locations each month from January to December in 2015. In brief, water was collected from a depth of $0.5 \mathrm{~m}$ below the surface, stored in glass containers at $0-4{ }^{\circ} \mathrm{C}$ in the dark, brought to the laboratory, and processed within $12 \mathrm{~h}$ for each sample based on standard methods [43]. Water temperature (WT), pH, dissolved oxygen (DO), and conductivity were measured in situ by use of YSI water quality sondes (YSI Incorporated, 6600V2-4, Ohio, USA). Water transparency (SD) was determined with a $30-\mathrm{cm}$ Secchi disk. Analysis of $\mathrm{COD}_{\mathrm{Cr}}, \mathrm{COD}_{\mathrm{Mn}}$, TP, TN, $\mathrm{BOD}_{5}, \mathrm{NH}_{4}{ }^{+}-\mathrm{N}, \mathrm{F}^{-}$,

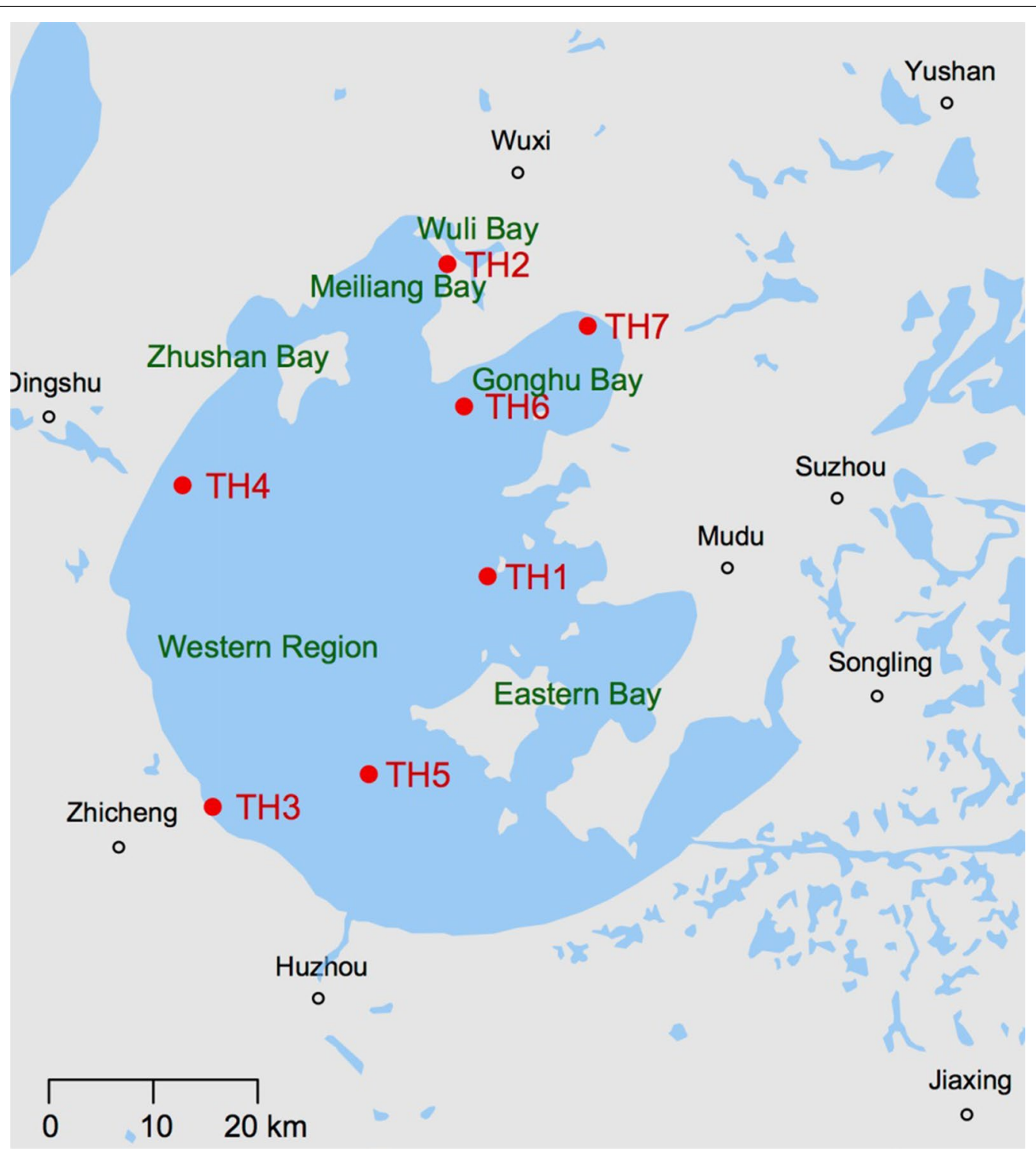

Fig. 1 Locations of seven sampling sites in Tai Lake 
As, $\mathrm{Pb}, \mathrm{Cu}$, and $\mathrm{Chl} a$ in water samples was based on a standard method [43]. Enzyme-linked immune sorbent assay (ELISA) was used to measure concentrations of MC-LR [44, 45], and the assay kits were bought from institute of hydrobiology of Chinese academy of sciences. The TN/TP ratio (NPR) was calculated. Based on five limnological parameters, including $\mathrm{SD}, \mathrm{COD}_{\mathrm{Mn}}$, TP, TN, and Chl $a$, the synthesized trophic state index (STSI) was calculated for each water sample and used to assess eutrophication status (Additional file 1: Table S1) [46-48].

\section{Collection of phytoplankton and analyses}

In brief, $1000 \mathrm{~mL}$ samples of water were collected at each location, and phytoplankton was fixed in acid Lugol's solution and transported to laboratory at $4{ }^{\circ} \mathrm{C}$ [43]. Identification of phytoplankton was performed to the species level and enumerated by counting at least 30 random fields in Sedgewick-Rafter sedimentation chambers (30 mL) using an inverted microscope (BX53, Olympus, Japan) [43, 49-51]. Numbers of cells of each taxon, as well as dimensions of individuals, including maximum linear dimension, were estimated. The dominant taxa were identified in the following equation [52]:

$$
Y=\left(n_{i} / N\right) f_{i},
$$

where $n_{i}$ is the number of cells of the $i$ th taxa, $f_{i}$ is the frequency of the $i$ th taxa appearing at the survey sites; $N$ is the number of phytoplankton taxa observed during the study. When $Y>0.02$, the taxa were classified as being dominant in the phytoplankton community.To determine diversity of phytoplankton communities, commonly used diversity indicators, included species richness $(S)$, the Shannon-Wiener index $\left(H^{\prime}\right)$, the Simpson index $\left(D_{\mathrm{s}}\right)$, the Berger and Parker index $\left(D_{\mathrm{b}}\right)$, and Pielou evenness index $(J)$ were calculated by PRIMER software version 6.1.10 (Lutton, Ivybridge, United Kingdom).

Species diversity was estimated by Shannon-Wiener index, Simpson index, and Berger-Parker index, which are members of Renyi diversity family, as given the following equation $[53,54]$ :

$$
\mathrm{HR}_{\alpha}=\frac{1}{1-\alpha} \log \sum_{i=1}^{s} P i^{\alpha} .
$$

This is a one-parametric diversity index family in which diversity of an assemblage is characterized by a diversity profile instead of a numerical value (Additional file 1: Fig. S1). By increasing the scale parameter $(\alpha)$, contributions of abundant species to the diversity of the assemblage increase, while contributions of rare species decrease. Researchers who want the index to be sensitive to the compositions of more abundant species but relatively indifferent to that of more rare species can use the diversity indices of Renyi family [55]. The values of Renyi diversity are lgS, $H^{\prime}, D_{\mathrm{s}}$, and $D_{\mathrm{b}}$ when the following $\alpha$ values were used $0,1,2$, and $\infty$ respectively.

\section{Data analyses}

Differences in water quality parameters or phytoplankton indicators during months or four seasons, and among seven sites in Tai Lake were analyzed by use of the Kruskal-Wallis, non-parametric test (SPSS 22.0, Chicago, Illinois, USA). A linear regression analysis was used to elucidate relationships between phytoplankton productivity (Chl $a$ ) and diversity metrics in Tai Lake (SPSS 22.0, Chicago, Illinois, USA). A $p$ value $<0.05$ was used as the threshold for statistical significance. The MultiResponse Permutation Procedure (MRPP, mrpp function in $\mathrm{R}$ package vegan) was used to determine differences in community composition and structure among locations and months. The null hypothesis was that there was no difference among the groups in a Monte Carlo randomization procedure with 999 permutations. To explore potential effects of environmental parameters on phytoplankton communities (Objective 2), the following preliminary data analyses were conducted. First, rare species with relative abundance $<0.5 \%$ when all samples were summed were excluded; this requirement reduced the number of taxa in the analysis from 124 to 31 . Second, species counts were converted to relative abundances (0-100\%), which were Hellinger transformed to reduce the weight of abundant species, while preserving Euclidean distances between samples in the multidimensional space [56]. Third, environmental variables with significant multicollinearity (with variance inflation factor $>10$ and Spearman's rank correlation coefficient $|r| \geq 0.75$ ) were excluded. STSI was removed due to its greater correlations with TP (Additional file 1: Table S2) and the other 17 environmental variables were included in the following analyses. A preliminary detrended correspondence analysis (DCA) on the species data produced a longest gradient length of 3.18 along the first axis, which suggested that redundancy analysis (RDA) was appropriate [57]. RDA was performed by use of the $r d a$ function and tested for significance using the anova function. Only when it was significant, forward selection and Monte Carlo permutations (999 iterations) were used to select variables that significantly $(p<0.05)$ explained the variance in species composition. Forward selection was performed by use of the envfit function in R package vegan. Furthermore, generalized linear models (GLMs) with Gaussian error distribution [58] were used to examine influencing factors of different algal indices (e.g., diversity indices, the dominant taxa) (Objective 3). The best 
approximating model was selected, based on Akaike's information criterion (AIC) [59], using function stepAIC in R package MASS. GLMs were performed with all environmental variables, except for STSI which was excluded due to its greater correlations with TP (see also above). The reason GLMs were selected rather than univariate analyses was because GLM models interpret importance of variables in a multivariate setting [60]. All these analyses were performed with $\mathrm{R}$ software version 3.3.2.

\section{Results}

\section{Water quality parameters}

Mean values of water quality parameters varied among seven sampling locations (Table 1). Concentrations of $\mathrm{Chl} a$, measuring of phytoplankton productivity that covered the whole trophic spectrum, ranged between 5.0 and $362 \mu \mathrm{g} / \mathrm{L}$ in Tai Lake. The largest synthesized trophic state index (STSI) was observed at TH4, while the least was observed at TH1. Greatest concentrations of MC-LR $(0.352 \mu \mathrm{g} / \mathrm{L})$ were observed at $\mathrm{TH} 2$, and least concentrations $(0.069 \mu \mathrm{g} / \mathrm{L})$ were observed at TH1. For concentrations of pollutants at the seven locations, TH4 seemed to be most contaminated, whereas TH1 (the eastern region) and TH5 (the central lake) were less contaminated $(p<0.000001)$.

\section{Phytoplankton community composition and diversity} During a period of January to December of 2015, 124 taxa of phytoplankton, including eight phyla 21 taxa Cyanophyta, 63 Chlorophyta, 25 taxa of Bacillariophyta, 3 Cryptophyta, 4 Pyrrophyta, 7 Euglenophyta, and 1 Chrysophyta, were found in Tai Lake. These taxa belonged to 68 genera, including 13 genera of Cyanophyta, 27 genera of Chlorophyta, 17 genera of Bacillariophyta, 2 genera of Cryptophyta, 4 genera of Pyrrophyta, 4 genera of Euglenophyta, and 1 genera of Chrysophyta, were observed. Over the 12 months, relatively large densities of phytoplankton were observed at all seven locations in Tai Lake (Additional file 1: Fig. S2), with the greatest density of approximately $9.0 \times 10^{8}$ cells/L at site TH4 in July. The second greatest density of phytoplankton was $7.4 \times 10^{8}$ cells/L, which was observed at TH3 in July. Among all these monitored locations, TH7 in Gonghu Bay exhibited

Table 1 Monthly values (mean \pm SD) of water parameters at seven sampling sites from January to December of 2015 in Tai Lake

\begin{tabular}{|c|c|c|c|c|c|c|c|c|}
\hline Items & TH1 & TH2 & TH3 & TH4 & TH5 & TH6 & TH7 & $P$ \\
\hline $\mathrm{WT}\left({ }^{\circ} \mathrm{C}\right)$ & $17.6 \pm 8.7$ & $18.8 \pm 9.0$ & $17.3 \pm 9.1$ & $17.6 \pm 8.8$ & $17.1 \pm 8.4$ & $18.6 \pm 8.9$ & $18.7 \pm 8.3$ & 0.999 \\
\hline $\mathrm{pH}$ & $8.22 \pm 0.34$ & $8.49 \pm 0.42$ & $8.16 \pm 0.46$ & $8.11 \pm 0.42$ & $8.18 \pm 0.44$ & $8.48 \pm 0.33$ & $8.29 \pm 0.29$ & 0.113 \\
\hline $\mathrm{SD}(\mathrm{m})$ & $0.33 \pm 0.05$ & $0.40 \pm 0.08$ & $0.27 \pm 0.08$ & $0.32 \pm 0.04$ & $0.30 \pm 0.03$ & $0.38 \pm 0.07$ & $0.37 \pm 0.05$ & $<0.0001^{* * *}$ \\
\hline $\mathrm{DO}(\mathrm{mg} / \mathrm{L})$ & $9.8 \pm 1.8$ & $10.7 \pm 1.5$ & $10.2 \pm 1.5$ & $10.1 \pm 1.7$ & $9.92 \pm 1.70$ & $10.2 \pm 1.6$ & $9.08 \pm 1.54$ & 0.336 \\
\hline $\begin{array}{l}\text { Conduc- } \\
\text { tivity } \\
\text { (ms/m) }\end{array}$ & $45.9 \pm 8.5$ & $50.1 \pm 5.4$ & $40.2 \pm 8.5$ & $49.0 \pm 13.8$ & $42.0 \pm 7.0$ & $50.5 \pm 5.6$ & $48.6 \pm 7.7$ & $<0.05^{*}$ \\
\hline $\begin{array}{l}\mathrm{COD}_{\mathrm{Mn}} \\
\quad(\mathrm{mg} / \mathrm{L})\end{array}$ & $3.6 \pm 0.8$ & $4.8 \pm 0.7$ & $3.8 \pm 0.8$ & $4.9 \pm 1.0$ & $3.6 \pm 0.6$ & $4.6 \pm 0.7$ & $4.0 \pm 0.7$ & $<0.0001^{* * *}$ \\
\hline $\begin{array}{l}\mathrm{BOD}_{5} \\
\quad(\mathrm{mg} / \mathrm{L})\end{array}$ & $1.4 \pm 0.5$ & $3.0 \pm 1.3$ & $2.1 \pm 1.4$ & $3.4 \pm 1.4$ & $1.6 \pm 0.3$ & $2.6 \pm 0.7$ & $2.8 \pm 0.7$ & $<0.0001^{* * *}$ \\
\hline TN (mg/L) & $1.44 \pm 0.68$ & $1.97 \pm 1.11$ & $1.75 \pm 1.07$ & $2.67 \pm 1.05$ & $1.39 \pm 0.73$ & $1.69 \pm 0.64$ & $1.88 \pm 0.74$ & $<0.05^{*}$ \\
\hline $\begin{array}{l}\mathrm{NH}_{4}^{+}-\mathrm{N} \\
\quad(\mathrm{mg} / \mathrm{L})\end{array}$ & $0.07 \pm 0.04$ & $0.10 \pm 0.05$ & $0.103 \pm 0.105$ & $0.228 \pm 0.229$ & $0.08 \pm 0.06$ & $0.10 \pm 0.06$ & $0.21 \pm 0.14$ & $<0.05^{*}$ \\
\hline $\mathrm{TP}(\mathrm{mg} / \mathrm{L})$ & $0.04 \pm 0.02$ & $0.07 \pm 0.04$ & $0.06 \pm 0.03$ & $0.10 \pm 0.02$ & $0.05 \pm 0.02$ & $0.06 \pm 0.03$ & $0.06 \pm 0.02$ & $<0.0005^{* * *}$ \\
\hline $\begin{array}{l}\text { Chl a } \\
\quad(\mu \mathrm{g} / \mathrm{L})\end{array}$ & $7.25 \pm 4.58$ & $69.2 \pm 109$ & $16.2 \pm 2.4$ & $64.1 \pm 7.6$ & $24.2 \pm 44.6$ & $14.8 \pm 6.6$ & $13.9 \pm 7.7$ & $<0.0005^{* * *}$ \\
\hline $\begin{array}{l}\mathrm{COD}_{\mathrm{Cr}} \\
\quad(\mathrm{mg} / \mathrm{L})\end{array}$ & $20 \pm 5$ & $25 \pm 7$ & $19 \pm 5$ & $25 \pm 9$ & $19 \pm 6$ & $25 \pm 6$ & $20 \pm 6$ & 0.065 \\
\hline $\mathrm{F}^{-}(\mathrm{mg} / \mathrm{L})$ & $0.621 \pm 0.079$ & $0.632 \pm 0.076$ & $0.615 \pm 0.100$ & $0.636 \pm 0.104$ & $0.607 \pm 0.102$ & $0.639 \pm 0.065$ & $0.553 \pm 0.043$ & 0.123 \\
\hline As (mg/L) & $0.0017 \pm 0.008$ & $0.0029 \pm 0.0024$ & $0.0019 \pm 0.0006$ & $0.0026 \pm 0.0019$ & $0.0019 \pm 0.004$ & $0.0027 \pm 0.0021$ & $0.0023 \pm 0.0014$ & 0.760 \\
\hline $\mathrm{Cu}(\mathrm{mg} / \mathrm{L})$ & $0.0039 \pm 0.0033$ & $0.0049 \pm 0.0055$ & $0.0034 \pm 0.0028$ & $0.0044 \pm 0.0037$ & $0.0035 \pm 0.0027$ & $0.0048 \pm 0.0057$ & $0.0043 \pm 0.0046$ & 0.998 \\
\hline $\mathrm{Pb}(\mathrm{mg} / \mathrm{L})$ & $0.0043 \pm 0.0058$ & $0.0056 \pm 0.0037$ & $0.0028 \pm 0.0033$ & $0.0044 \pm 0.0053$ & $0.0042 \pm 0.0061$ & $0.0050 \pm 0.0044$ & $0.0073 \pm 0.0066$ & 0.425 \\
\hline $\begin{array}{l}\text { MC-LR } \\
\quad(\mu \mathrm{g} / \mathrm{L})\end{array}$ & $0.069 \pm 0.036$ & $0.352 \pm 0.349$ & $0.091 \pm 0.039$ & $0.242 \pm 0.196$ & $0.098 \pm 0.058$ & $0.234 \pm 0.281$ & $0.116 \pm 0.081$ & $<0.005^{* *}$ \\
\hline NPR & $55.7 \pm 45.4$ & $48.6 \pm 63.0$ & $32.1 \pm 19.0$ & $28.0 \pm 13.4$ & $33.1 \pm 19.4$ & $48.2 \pm 62.9$ & $35.2 \pm 15.8$ & 0.690 \\
\hline STSI & $49.3 \pm 3.3$ & $57.6 \pm 6.3$ & $54.0 \pm 4.7$ & $61.0 \pm 5.1$ & $52.5 \pm 4.0$ & $54.5 \pm 2.7$ & $54.1 \pm 2.5$ & $<0.00005^{* * *}$ \\
\hline $\begin{array}{l}\text { Trophic } \\
\text { state }\end{array}$ & Mesotrophication & Eutrophication & Eutrophication & $\begin{array}{l}\text { Supereutrophica- } \\
\text { tion }\end{array}$ & Eutrophication & Eutrophication & Eutrophication & / \\
\hline
\end{tabular}


lesser densities of phytoplankton, ranging from $2.1 \times 10^{6}$ to $6.8 \times 10^{7}$ cells/L over the 12 months $(p=0.009)$.

In the present study, Cyanophyta was the dominant phylum in Tai Lake, with a mean percentage of abundance of $79.5 \%$, followed by Chlorophyta, Bacillariophyta and Cryptophyta, with relative abundances of 12.9, 6.2 and 1.3\%, respectively. Assemblages of phytoplankton in Tai Lake were dominated by Cyanophyta, including Microcystis sp. $(Y=0.80)$ and Dolichospermum flos-aquae $(Y=0.08)$. Based on monthly data, Dolichospermum flos-aquae was the dominant species in Tai Lake from February to March; Planctonema sp. of Chlorophyta was the most dominant species in May, while Microcystis sp. was dominant taxa in the nine other months (Fig. 2). In addition, Microcystis sp. was the absolutely dominant taxa from June to December. Meanwhile, average percentage of Microcystis sp. density in the phytoplankton community at TH4 was greatest to about $65.9 \%$, followed by $\mathrm{TH} 2$ and TH6, with 63.0 and $57.0 \%$, respectively (Table 2). Phytoplankton indicators at the seven locations in Tai Lake are shown in Table 2. The diversity of $H^{\prime}$ and $J$ at TH5 was greatest among the seven locations, while TH4 was the least $(p<0.01)$. Differences in phytoplankton indicators were significant among four seasons in Tai Lake. Diversity $\left(D_{\mathrm{s}}, H^{\prime}\right.$ and $\left.D_{\mathrm{b}}\right)$ and evenness $(\zeta)$ of phytoplankton communities in spring were greatest among four seasons in Tai Lake, while diversity of phytoplankton was least in summer (Additional file 1: Fig. S3). Differences in structures of phytoplankton communities were significant among seven locations in Tai Lake (MRPP: $A=0.031, p<0.05)$, and differences in structures of communities of phytoplankton were also significant among months (MRPP: $A=0.242, p<0.01$ ).

\section{Relationships between species composition and environmental variables}

Using a linear regression analysis, the relationships between phytoplankton productivity and diversity of $S, D_{\mathrm{s}}, H^{\prime}, J$, and $D_{\mathrm{b}}$ are shown in Fig. $3\left(r^{2}=0.132\right.$,
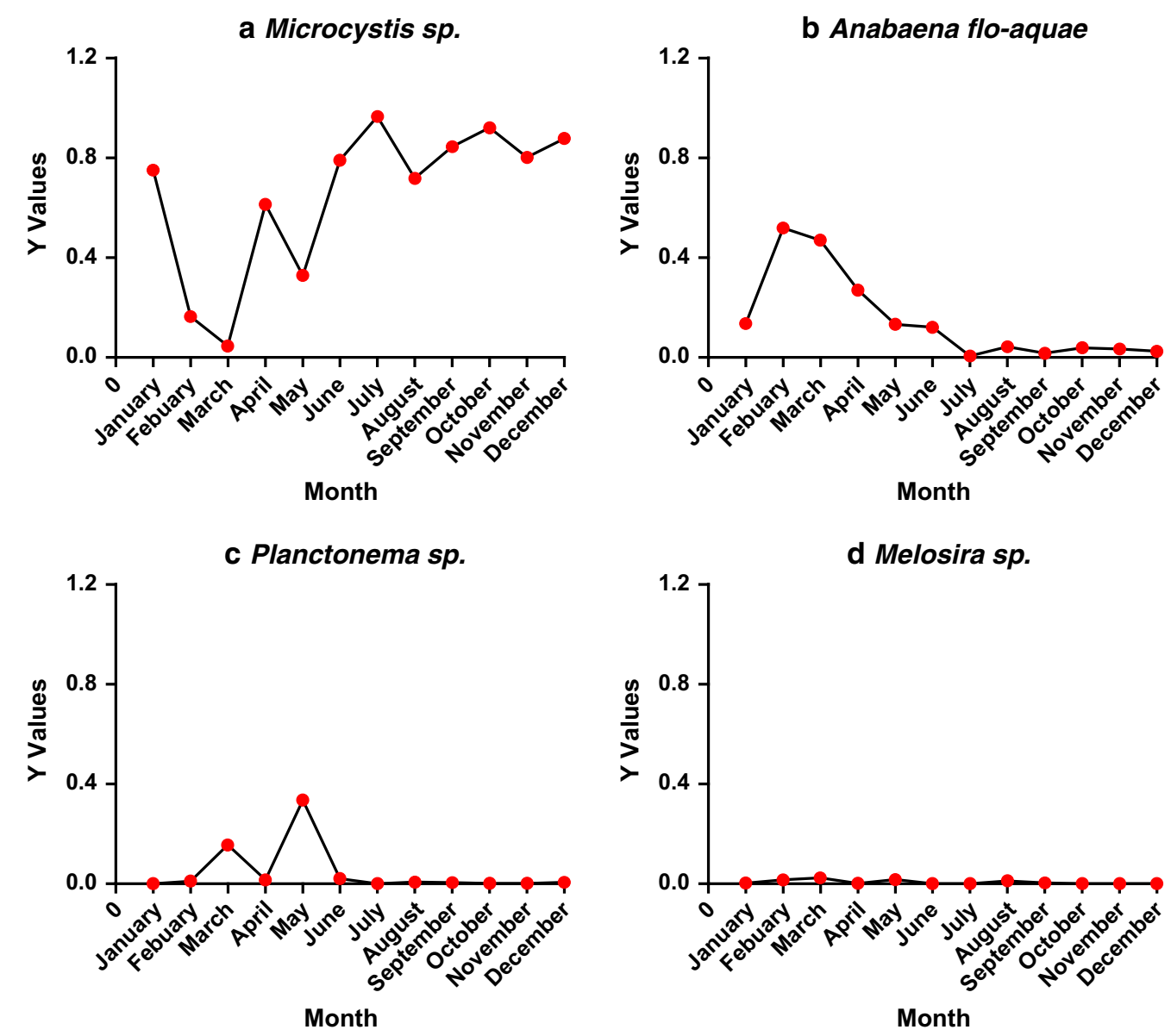

Fig. 2 Percentages of dominant taxa (Microcystis sp., Anabaena flos-aquae, Planctonema sp. and Melosira sp.) in phytoplankton community and their temporal changes from January to December of 2015 in Tai Lake 
Table 2 Percentages (mean \pm SD) of densities of dominant taxa and values (mean \pm SD) of phytoplankton indicators (diversity) at seven sampling sites from January to December of 2015 in Tai Lake

\begin{tabular}{|c|c|c|c|c|c|c|c|c|}
\hline Items & TH1 & TH2 & TH3 & TH4 & TH5 & TH6 & TH7 & $P$ \\
\hline P Cyanophyta \% & $76.2 \pm 23.3$ & $87.3 \pm 19.7$ & $86.8 \pm 16.4$ & $96.2 \pm 3.5$ & $69.5 \pm 24.0$ & $85.2 \pm 20.0$ & $55.4 \pm 37.5$ & ** \\
\hline P Chlorophyta \% & $18.9 \pm 21.6$ & $6.1 \pm 9.4$ & $11.0 \pm 16.0$ & $2.3 \pm 2.4$ & $25.5 \pm 21.4$ & $9.2 \pm 13.3$ & $17.3 \pm 25.5$ & $*$ \\
\hline P Bacillariophyta \% & $3.7 \pm 3.1$ & $5.7 \pm 9.4$ & $1.7 \pm 1.6$ & $1.2 \pm 1.4$ & $3.6 \pm 3.4$ & $4.7 \pm 7.1$ & $22.5 \pm 28.8$ & $*$ \\
\hline P Cryptophyta \% & $1.1 \pm 0.9$ & $0.8 \pm 1.6$ & $0.4 \pm 0.3$ & $0.3 \pm 0.2$ & $1.3 \pm 0.7$ & $0.8 \pm 1.3$ & $4.5 \pm 8.5$ & ** \\
\hline P Microcystis sp. \% & $50.3 \pm 32.8$ & $63.0 \pm 35.3$ & $45.1 \pm 32.8$ & $65.9 \pm 36.5$ & $40.7 \pm 29.1$ & $56.9 \pm 34.7$ & $44.0 \pm 34.0$ & n.s. \\
\hline P Anabaena flos-aquae \% & $18.2 \pm 18.7$ & $18.4 \pm 21.0$ & $26.6 \pm 24.8$ & $26.6 \pm 33.0$ & $24.3 \pm 23.6$ & $15.3 \pm 20.7$ & $1.8 \pm 3.6$ & $*$ \\
\hline P Planctonema sp. \% & $18.9 \pm 21.6$ & $6.1 \pm 9.4$ & $11.0 \pm 16.0$ & $2.3 \pm 2.4$ & $25.5 \pm 21.4$ & $9.2 \pm 13.3$ & $17.3 \pm 25.5$ & $* *$ \\
\hline P Melosira sp. \% & $1.4 \pm 2.2$ & $1.6 \pm 2.2$ & $1.1 \pm 1.3$ & $0.6 \pm 0.8$ & $2.3 \pm 2.8$ & $0.6 \pm 0.9$ & $1.3 \pm 2.9$ & n.s. \\
\hline Taxa-S & $14 \pm 2$ & $15 \pm 6$ & $19 \pm 8$ & $15 \pm 4$ & $15 \pm 4$ & $17 \pm 5$ & $14 \pm 3$ & n.s. \\
\hline$D_{s}$ & $0.51 \pm 0.25$ & $0.39 \pm 0.26$ & $0.53 \pm 0.24$ & $0.27 \pm 0.22$ & $0.57 \pm 0.16$ & $0.46 \pm 0.26$ & $0.52 \pm 0.21$ & n.s. \\
\hline$H^{\prime}$ & $1.14 \pm 0.55$ & $0.89 \pm 0.58$ & $1.21 \pm 0.62$ & $0.61 \pm 0.46$ & $1.28 \pm 0.43$ & $1.11 \pm 0.69$ & $1.24 \pm 0.50$ & $*$ \\
\hline$J$ & $0.26 \pm 0.12$ & $0.20 \pm 0.11$ & $0.22 \pm 0.11$ & $0.14 \pm 0.07$ & $0.26 \pm 0.09$ & $0.21 \pm 0.11$ & $0.29 \pm 0.13$ & * \\
\hline$D_{\mathrm{b}}$ & $0.23 \pm 0.16$ & $0.17 \pm 0.17$ & $0.25 \pm 0.17$ & $0.10 \pm 0.10$ & $0.26 \pm 0.15$ & $0.24 \pm 0.24$ & $0.21 \pm 0.14$ & n.s. \\
\hline
\end{tabular}

P Cyanophyta: percent of Cyanophyta density among the phytoplankton community; P Chlorophyta: percent of Chlorophyta density among the phytoplankton community; P Bacillariophyta: percent of Bacillariophyta density among the phytoplankton community; P Cryptophyta: percent of Cryptophyta density among the phytoplankton community; P Microcystis sp.: percent of Microcystis sp. density among the phytoplankton community

${ }^{*} p<0.05 ;{ }^{* *} p<0.005 ;$ n.s not significant

$p=0.232 ; \mathrm{R} r^{2}=-0.432, p<0.001 ; r^{2}=-0.392, p<0.001$; $r^{2}=-0.418, p<0.001 ; r^{2}=-0.323, p<0.01$, respectively). The species richness was positively, though not significantly, associated with productivity of phytoplankton (Fig. 3a), while significantly inverse relationships for the other four metrics of $D_{\mathrm{s}}, H^{\prime}, J$, and $D_{\mathrm{b}}$ (Fig. 3b-e).

RDA was carried out on 17 environmental variables against Hellinger-transformed abundance species data with 999 permutations and significant relationships were determined by use of a global test $(F=2.446, p<0.001)$. Among the 17 environmental variables, 11 parameters (WT, pH, SD, DO, $\mathrm{COD}_{\mathrm{Mn}}, \mathrm{BOD}_{5}, \mathrm{TP}, \mathrm{COD}_{\mathrm{Cr}}, \mathrm{F}^{-}$, As and MC-LR) were significantly correlated $(p<0.05,999$ Monte Carlo permutations, Table 3) and accounted for $33.5 \%$ of the variance in the algae data. The first RDA axis, representing $21.5 \%$ variance of the species data, was significantly associated with WT, $\mathrm{pH}, \mathrm{SD}, \mathrm{DO}, \mathrm{COD}_{\mathrm{Cr}}$, $\mathrm{F}^{-}$, As and MC-LR. RDA axis 2 contributed additional $6.3 \%$ to the explained variance and was characterized significantly by $\mathrm{COD}_{\mathrm{Mn}}, \mathrm{BOD}_{5}$ and TP (Table 3 ).

\section{Factors associating with phytoplankton indicators}

Relationships among various indices, including diversity indices, dominant taxa and environmental variables were analyzed by use of generalized linear models (GLMs). WT, $C O D_{M n}, B_{5}, M C-L R$ and NPR were the main factors that affected most parameters (Table 4). Several parameters, such as Chl $a, S$, total density, Microcystis sp., Melosira sp., Cyanophyta, Chlorophyta, and percent of Dolichospermum flos-aquae density were significantly related with WT (Table 4). Phytoplankton diversity indices $\left(H^{\prime}, J\right.$ and $\left.D_{\mathrm{b}}\right)$ were significantly related with $\mathrm{BOD}_{5}, \mathrm{MC}$-LR and NPR.

\section{Discussion}

\section{Temporal changes in phytoplankton communities of Tai} Lake

Tai Lake is a large shallow lake, which provides hospitable environment for phytoplankton, and phytoplankton communities have changed over time (Table 5). In the 1960s, there were 91 genera of phytoplankton belonging to eight phyla, which were more frequently observed compared to the present study. Although the mean percent of Cyanophyta among constituents of phytoplankton density was $96.6 \%$ in the western area of the lake in 1960s, the greatest density of total phytoplankton was only $6.6 \times 10^{5}$ cells/L in Tai Lake [61], and were much less than densities observed in this study (Additional file 1: Fig. S2). Meanwhile, at that time, the community was dominated by Bacillariophyta-Chlorophyta in TH3, which is in the southwest of the lake. Concentrations of nutrients (Nitrogen: $0.15 \mathrm{mg} / \mathrm{L}, \mathrm{PO}_{4}{ }^{3-} \mathrm{P}: 0.05 \mathrm{mg} / \mathrm{L}$ ) and pollutants $\left(\mathrm{COD}_{\mathrm{Mn}}: 1.90 \mathrm{mg} / \mathrm{L}\right)$ in the whole Tai Lake were also less than those measured here (Table 1). Since 1980 s, cell density of phytoplankton increased in the rate of 5.8 times per year. Subsequently, blooms of cyanobacteria led to a drinking water crisis in summer of 2007; numbers of phytoplankton in Meiliang Bay ranged from $3.0 \times 10^{6}$ to $3.7 \times 10^{9}$ cells $/ \mathrm{L}$, with a maximum density of phytoplankton occurring in June in 2008 [62].

The structure of the phytoplankton community in Tai Lake is still changing but in a good direction. In the 

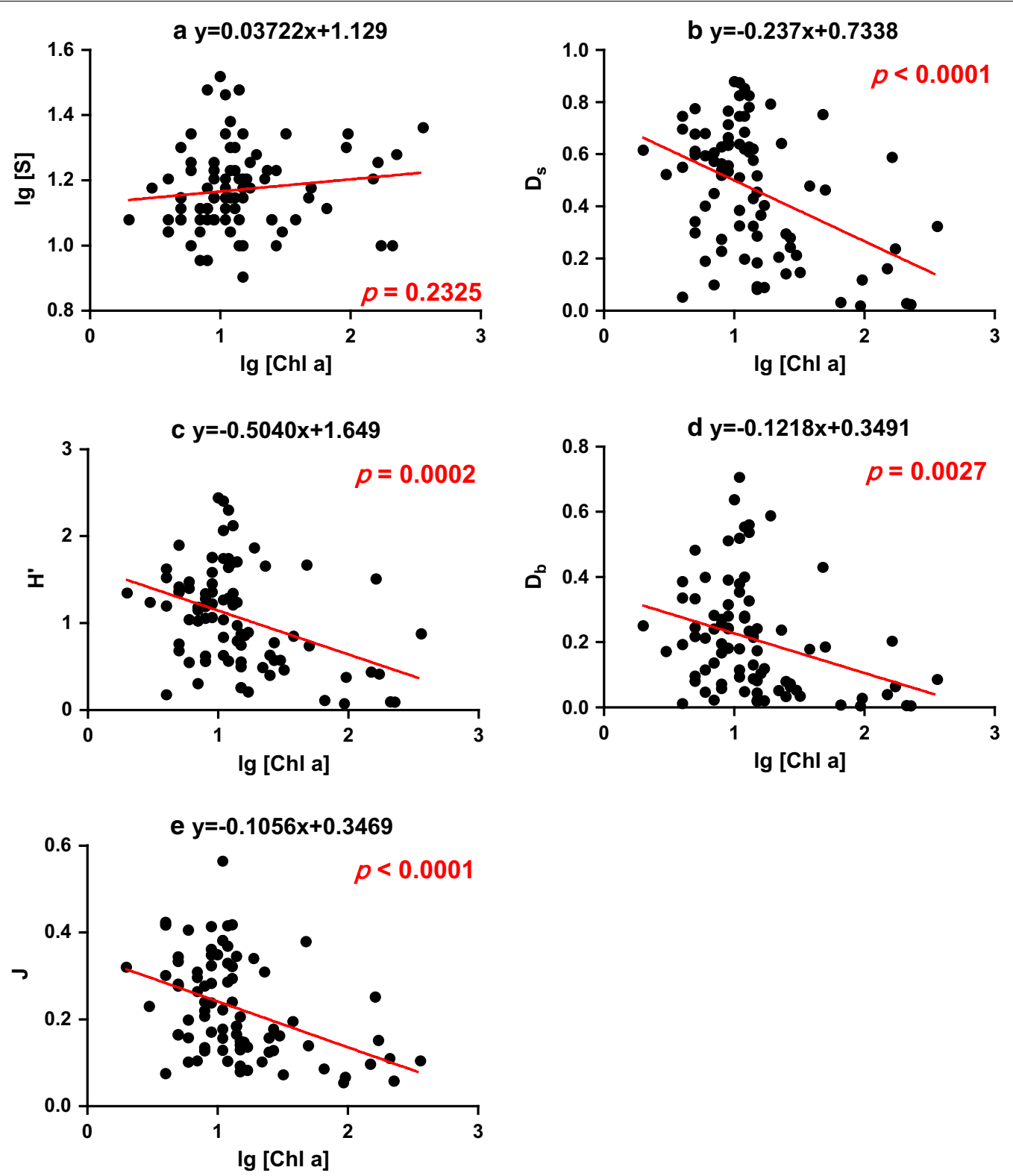

Fig. 3 Scatter plots and linear regressions between productivity of phytoplankton (expressed in Chl $a$; log transformed) and measures of diversity of the phytoplankton community ( $\left(\log\right.$ transformed), $D_{s^{\prime}} H^{\prime}, D_{b}$ and $\Omega$ ) in Tai Lake. The curves were fitted based on $n=84$ data points. The equation and $p$ value for the specific linear regressions are given in each panel

present study, Microcystis sp. and Dolichospermum flosaquae of Cyanophyta, and Planctonema sp. of Chlorophyta were still predominant taxa observed (Fig. 2). Numbers of phytoplankton at the seven locations studied ranged from $2.5 \times 10^{6}$ to $9.0 \times 10^{8}$ cells/L. In Meiliang Bay, the number of phytoplankton ranged from $3.2 \times 10^{6}$ to $2.4 \times 10^{8}$ cells/L, that was less than that in 2008 [62]. This result was probably because nitrogen and phosphorus have been controlled in Tai Lake since the drinking water crisis of 2007. Many ecological restoration projects used a wetland system to treat the rural wastewater removing nitrogen in the Lake [63]. Therefore, concentrations of TN and TP observed in 2015 were less than reported before [64].

In the present study, numbers of cells of cyanobacteria were still high in the lake, and concentrations of $\mathrm{N}$ and $\mathrm{P}$ were still greater than the thresholds of 0.80 and $0.05 \mathrm{mg} / \mathrm{L}$, respectively, limiting blooms of Microcystis in Tai Lake [38]. In 2015, 68 genera of phytoplankton among seven phyla were observed, which was less than 
Table 3 Results of forward selection with 999 Monte Carlo permutations of environmental variables for species composition

\begin{tabular}{lrrll}
\hline Variables & \multicolumn{1}{c}{ RDA1 } & \multicolumn{1}{c}{ RDA2 } & $\boldsymbol{R}^{\mathbf{2}}$ & $\boldsymbol{P}$ value \\
\hline $\mathrm{WT}$ & 0.892 & 0.452 & 0.240 & $0.001^{* * *}$ \\
$\mathrm{pH}$ & 0.769 & 0.639 & 0.110 & $0.013^{*}$ \\
$\mathrm{SD}$ & 0.960 & -0.279 & 0.086 & $0.017^{*}$ \\
$\mathrm{DO}$ & -0.738 & -0.675 & 0.201 & $0.001^{* * *}$ \\
$\mathrm{Conductivity}$ & -0.999 & 0.053 & 0.063 & 0.080 \\
$\mathrm{COD}_{\mathrm{Mn}}$ & -0.036 & -0.999 & 0.129 & $0.002^{* *}$ \\
$\mathrm{BOD}_{5}$ & 0.662 & -0.750 & 0.100 & $0.016^{*}$ \\
$\mathrm{TN}^{+}$ & -0.967 & -0.256 & 0.023 & 0.36 \\
$\mathrm{NH}_{4}{ }^{-} \mathrm{N}$ & 0.973 & -0.232 & 0.025 & 0.35 \\
$\mathrm{TP}$ & 0.603 & -0.798 & 0.080 & $0.026^{*}$ \\
$\mathrm{COD}_{\mathrm{Cr}}$ & -0.943 & -0.334 & 0.091 & $0.025^{*}$ \\
$\mathrm{~F}^{-}$ & -0.884 & -0.467 & 0.417 & $0.001^{* * *}$ \\
$\mathrm{As}$ & 0.982 & -0.190 & 0.128 & $0.005^{* *}$ \\
$\mathrm{Cu}$ & -0.859 & 0.511 & 0.007 & 0.764 \\
$\mathrm{~Pb}$ & 0.678 & 0.735 & 0.063 & 0.069 \\
$\mathrm{MC}-\mathrm{LR}$ & 0.803 & -0.596 & 0.108 & $0.007^{* *}$ \\
$\mathrm{NPR}$ & -0.976 & 0.219 & 0.025 & 0.347 \\
\hline
\end{tabular}

Correlations with RDA 1 and RDA2, $R^{2}$ and $p$ values are shown. Significance was expressed as ${ }^{*} p<0.05,{ }^{* *} p<0.01$, and ${ }^{* * *} p<0.001$

the 91 genera in eight phyla in 1960s [61]. The dominance (Y) of Microcystis sp. in Tai Lake was the greatest (Fig. 2), which was consistent with results of a previous study that phytoplankton of eutrophic shallow lakes was frequently dominated by one species or species of the same functional group, resulting in species-pure algal assemblages [65]. Phyla including Pyrrophyta, Euglenophyta and Chrysophyta appeared rarely in Tai Lake, which is consistent with the previous studies in eutrophic waters [66]. As nutrient concentrations and phytoplankton blooms were increasing, transparency was low in Tai Lake and cyanobacteria can outcompetes subsurface phytoplankton species by reducing photosynthetically available light through shading $[67,68]$.

\section{Relationships between phytoplankton productivity and diversity}

In general, diversity curves are either concave-down or exhibit increasing functions with productivity $[55,69]$. Retention and concentrations of nutrients are relatively high and residence time is long in Tai Lake [35]. Thus, the morphometric and hydrologic parameters are favorable for development of great biomasses of phytoplankton. In the present study, various shapes of relationships between productivity and diversity were observed. Diversity metrics of $H^{\prime}, D_{\mathrm{s}}, D_{\mathrm{b}}$ and $J$ showed similar changes along the productivity gradient in Tai Lake (Fig. 3b-e).
An inverse relationship was observed between diversity of the phytoplankton community and primary production in Tai Lake. Results of a previous study [65] have demonstrated that dominance of bloom-forming cyanobacteria that can more successfully compete for light, exerted strong negative effects on other species of phytoplankton. In contrast, the logarithm of species richness was slightly and positively correlated with primary productivity in Tai Lake, which was consistent with previous findings [70], showing that productivity could determine the upper values of diversity metrics and lesser values of species richness were found in the whole productivity range. The results of previous studies that focused on the decisive role of physical disturbances in determining diversity and the productivity-diversity relationship for phytoplankton in lakes, suggested that the relationships between productivity and diversity can be used to assess ecological state [70, 71]. The results of this study indicated that diversity of phytoplankton communities is significantly related to trophic status and overall primary production in Tai Lake.

\section{Factors effecting on structure of the phytoplankton community}

WT, $\mathrm{pH}, \mathrm{COD}_{\mathrm{Mn}}, \mathrm{BOD}_{5}$, TP, NPR, As and MC-LR were the main factors effecting structures of the phytoplankton community in Tai Lake (Tables 3 and 4). The $\mathrm{pH}$ (from 7.29 to 9.07) in 2015 was greater than those (from 7.30 to 8.10 ) observed in the $1960 \mathrm{~s}$, and numbers of cyanobacteria was greater than they were in 1960s [61]. When photosynthesis of algae consumed inorganic carbon, the carbonate-buffering capacity of the Tai lake was decreased, which increased $\mathrm{pH}[72,73]$. The researchers explained that photosynthesis is increasing $\mathrm{pH}$ by $\mathrm{CO}_{2}$ consumption; cyanobacteria have the ability to use $\mathrm{HCO}_{3}{ }^{-}$[74] which could be part of their competitive advantage under higher $\mathrm{pH}$ conditions.

Temperature is a crucial factor affecting the composition of the phytoplankton community, and greater numbers of cells usually observe in warmer seasons [14]. Furthermore, temperature is the most important factor controlling which phytoplankton taxa is present in freshwater lakes [75, 76]. Results of the current study are consistent with results of previous studies [77-80], and showing that cyanobacteria-dominated phytoplankton communities in warmer seasons. Once critical concentrations of nutrients were exceeded, temperature was the principal factor driving blooms of Microcystis [81, 82]. Compared with Bacillariophyta, Cyanophyta have a competitive advantage under conditions of greater temperature, especially when temperature of water exceeds $25{ }^{\circ} \mathrm{C}[13,83]$. In addition, Gala and Giesy [84] demonstrated that UV light can penetrate into water, especially 
Li et al. Environ Sci Eur (2018) 30:27

Page 10 of 15

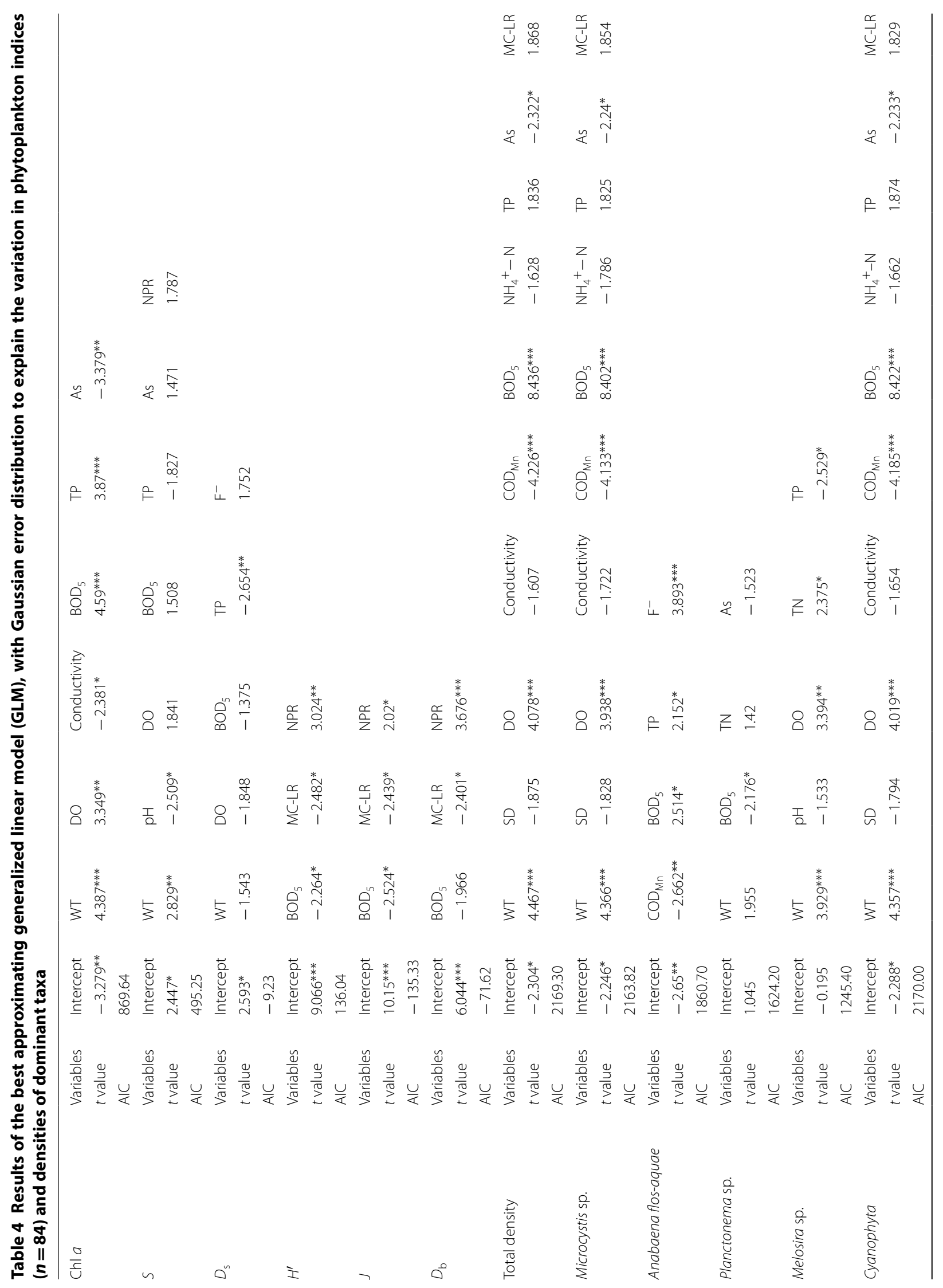




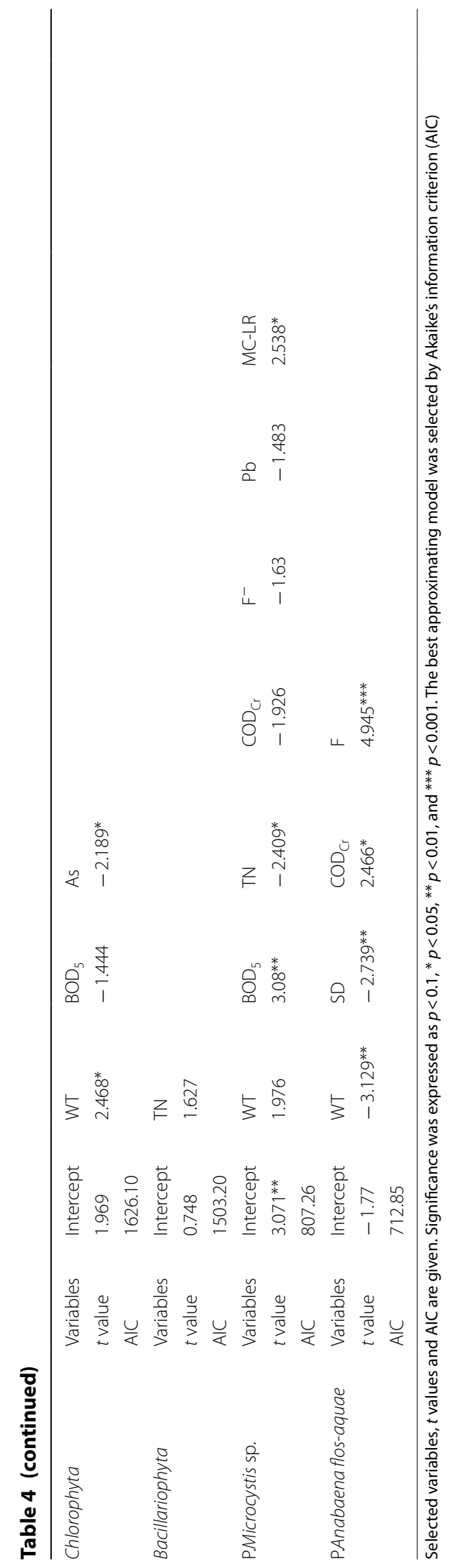


Table 5 Comparaison of changes in numbers of phytoplankton communities at the genus level of Tai Lake in 1960s and the present study (2015)

\begin{tabular}{|c|c|c|c|c|c|c|c|c|c|}
\hline $\begin{array}{l}\text { The } \\
\text { studies }\end{array}$ & Cyanophyta & Chlorophyta & Bacillariophyta & Cryptophyta & Pyrrophyta & Euglenophyta & Chrysophyta & Xanthophyceae & $\begin{array}{l}\text { Total } \\
\text { number } \\
\text { of genus }\end{array}$ \\
\hline $1960 \mathrm{~s}$ & 15 & 48 & 18 & 0 & 2 & 5 & 1 & 2 & 91 \\
\hline $\begin{array}{l}\text { Our study } \\
\text { (2015) }\end{array}$ & 13 & 27 & 17 & 2 & 4 & 4 & 1 & 0 & 68 \\
\hline
\end{tabular}

in shallow lakes, and that phytoplankton exhibited differential sensitivities. Hence, there can be seasonal changes in relative densities due to these differential sensitivities and cyanobacteria are the least sensitive class of taxa. Even though arsenic (As) can isomorphically substitute for phosphorus (P), it was not conducive to growth of algae. In the present study, significantly negative correlations between concentrations of As and concentrations of Chl $a$ and total numbers of phytoplankton were observed (Table 4). Phytoplankton can be involved in geochemical cycling of As in aquatic ecosystems [85, 86]. In fact, there are some phytoplankton, especially cyanobacteria, that are resistant to adverse effects of As $[87,88]$, because they contain a class of proteins similar to metallothioneins [89] and could accumulate and transform As. Concentrations of phosphorus cannot rescue other species from the toxic effects of As.

Since growth and reproduction of phytoplankton requires absorption of nutrients, such as $\mathrm{N}$ and $\mathrm{P}$, concentrations of these nutrients have an important impact on structures of phytoplankton communities [38, 90, 91]. Species richness of phytoplankton changed as a function of the ratio of $\mathrm{N}$ to $\mathrm{P}$ (NPR) $[92,93]$. In Tai Lake, Microcystis spp. was the most competitive among taxa of phytoplankton. This observation is supported by the significantly negative relationship between concentrations of MC-LR and indicators of diversity $\left(H^{\prime}, J\right.$ and $\left.D_{\mathrm{b}}\right)$ of the phytoplankton community (Table 4). Results of this study also demonstrated that Cyanophyta, such as Microcystis spp., had a negative effect on growth and relative proportions of other phytoplankton. Toxins derived from cyanobacteria can reduce the growth of diatoms [94]. Specifically, Microcystis spp. and Pseudanabaena spp. can produce extracellular products that are toxic to both aquatic organisms and humans [95-97]. Our findings indicated that blooms of Microcystis resulted in less stability of structure of the phytoplankton community. This result was consistent with a previous study, in which extracellular products of Cyanophyta promoted clustering of cyanobacterial cells, which might be due to the toxins inducing algal cells to release polysaccharides [98]. Furthermore, formation of clusters helped cyanobacteria in escaping predation by zooplankton [99]. Collectively, results of the present study demonstrated that MC-LR was significantly and negatively associated with diversity of aquatic communities, which were consistent with results of a previous study (Li et al. [32]).

\section{Conclusions}

The present study investigated the structure of the phytoplankton community over a period of January to December of 2015 in Tai Lake and demonstrated that the structure of phytoplankton community was changed as the changing concentrations of nutrients and other stressors. WT, $\mathrm{pH}$, permanganate index $\left(\mathrm{COD}_{\mathrm{Mn}}\right), \mathrm{BOD}_{5}$, TP, As, TN/TP ratio (NPR) and MC-LR were the main factors that influenced the structure of the phytoplankton community in Tai Lake. The results demonstrated that Simpson, Shannon-Wiener, Berger and Parker and the Pielou evenness indices could be used to assess and monitor for status and trends in water quality of Tai Lake. This research will be helpful in understanding the changing environment on biodiversity in aquatic ecosystems.

\section{Additional file}

Additional file 1: Figure S1. Profiles of diversity represented by one-parametric Renyi diversity index for two hypothetical assemblages, denoted by $A$ and $B$. Vertical dotted lines denote values of the scale parameter (measured along the $x$-axis), which provides classical diversity index statistics, such as number of species, Shannon, Simpson, and Berger-Parker index of diversity. Figure S2. Densities of phytoplankton taxa of seven sampling sites in Tai Lake. Figure S3. Diversities of phytoplankton communities at four different seasons in Tai Lake. Table S1. Synthesized index of trophic state (STSI), trophic state, and qualitative descriptor of water quality. Table S2. Pairwise Spearman's correlations coefficients $(\rho)$ among environmental variables.

\section{Authors' contributions}

$\mathrm{DL}$ initiated the first draft of the manuscript. All authors contributed to the content in various ways. All authors read and approved the final manuscript.

\section{Author details}

' State Key Laboratory of Pollution Control and Resource Reuse, School of the Environment, Nanjing University, Nanjing, Jiangsu 210046, China. 2 Jiangsu Environmental Monitoring Center, Nanjing, Jiangsu 210036, China. ${ }^{3}$ Department of Hydrology and Water Resources Management, Kiel University, Kiel 24118, Germany. ${ }^{4}$ National Institute of Environmental Health, Chinese Center for Disease Control and Prevention, Beijing 100021, China. ${ }^{5}$ Jiangsu Key Laboratory of Chemical Pollution Control and Resources Reuse, School of Environmental and Biological Engineering, Nanjing University of Science 
and Technology, Nanjing 210094, China. ${ }^{6}$ School of the Environment, Nanjing Normal University, Nanjing, Jiangsu 210023, China. ${ }^{7}$ Wuxi Environmental Monitoring Center, Wuxi, Jiangsu 214000, China. ${ }^{8}$ Toxicology Centre, University of Saskatchewan, Saskatoon, SK S7N 5B3, Canada. ${ }^{9}$ School of Environment and Sustainability, University of Saskatchewan, Saskatoon, SK S7N 5C3, Canada. ${ }^{10}$ Department of Veterinary Biomedical Sciences and Toxicology Centre, University of Saskatchewan, Saskatoon, SK S7N5B3, Canada. ${ }^{11}$ Department of Zoology and Center for Integrative Toxicology, Michigan State University, East Lansing, MI 48824, USA. ${ }^{12}$ School of Biological Sciences, University of Hong Kong, Hong Kong, SAR, China.

\section{Acknowledgements}

The authors would like to thank Suzhou Municipal Environmental Monitoring Center and Wuxi Municipal Environmental Monitoring Center.

\section{Competing interests}

The authors declare that they have no competing interests.

\section{Availability of data and materials}

Not applicable.

\section{Consent for publication}

Not applicable.

\section{Ethics approval and consent to participate} Not applicable.

\section{Funding}

This work was financially supported by the National Major Science and Technology Program for Water Pollution Control and Treatment (2013ZX07502001005) and by the general office of Lake Taihu Water Pollution Prevention and Control, Jiangsu Province in China (TH2014207). Prof. Giesy was supported by the "Great Level Foreign Experts" program (\#GDT20143200016) funded by the State Administration of Foreign Experts Affairs, the P.R. China to Nanjing University and the Einstein Professor Program of the Chinese Academy of Sciences. He was also supported by the Canada Research Chair program and a Distinguished Visiting Professorship in the School of Biological Sciences of the University of Hong Kong.

\section{Publisher's Note}

Springer Nature remains neutral with regard to jurisdictional claims in published maps and institutional affiliations.

\section{Received: 30 March 2018 Accepted: 11 June 2018}

Published online: 28 July 2018

\section{References}

1. Hillebrand H, Matthiessen B (2010) Biodiversity in a complex world: consolidation and progress in functional biodiversity research. Ecol Lett 12(2):1405-1419

2. Humphries CJ, Williams PH, Vane-Wright RI (1995) Measuring biodiversity value for conservation. Annu Rev Ecol Syst 26:93-111

3. Hartwell SI, Dawson CE, Durell EQ, Alden RW, Adolphson PC, Wright DA, Coelho GM, Magee JA, Ailstock S, Norman M (1997) Correlation of measures of ambient toxicity and fish community diversity in Chesapeake Bay, USA, tributaries-urbanizing watersheds. Environ Toxicol Chem 16:2556-2567

4. Chen Y, Fan C, Teubner K, Dokulil M (2003) Changes of nutrients and phytoplankton chlorophyll-a in a large shallow lake, Taihu, China: an 8-year investigation. Hydrobiologia 506-509:273-279

5. Krzton W, Pudas K, Pociecha A, Strzesak M, Kosiba J, Walusiak E, SzarekGwiazda E, Wilk-Wozniak E (2016) Microcystins affect zooplankton biodiversity in oxbow lakes. Environ Toxicol Chem. https://doi.org/10.1002/ etc.3519

6. Hotzel G, Croome R (1999) A phytoplankton methods manual for Australian freshwaters. Land and Water Resources Research and Development Corporation, Australian Capitol Territory, AUS, p 58
7. McCormick P, Cairns JJ (1994) Algae as indicators of environmental change. J Appl Phycol 6:509-526

8. Liu L, Yang J, Lv H, Yu X, Wilkinson DM, Yang J (2015) Phytoplankton communities exhibit a stronger response to environmental changes than bacterioplankton in three subtropical reservoirs. Environ Sci Technol 49:10850-10858

9. Spatharis S, Tsirtsis G, Danielidis DB, Chi TD, Mouillot D (2007) Effects of pulsed nutrient inputs on phytoplankton assemblage structure and blooms in an enclosed coastal area. Estuar Coast Shelf Sci 73:807-815

10. Tolotti M, Thies H, Nickus U, Psenner R (2012) Temperature modulated effects of nutrients on phytoplankton changes in mountain lake. Hydrobiologia 698:61-75

11. Padisak J (1992) Seasonal succession of phytoplankton in a large shallow lake (Balaton, Hungary) - a dynamic approach to ecological memory, its possible role and mechanisms. J Ecol 80:217-230

12. Das P, Metcalfe CD, Xenopoulos MA (2014) Interactive effects of silver nanoparticles and phosphorus on phytoplankton growth in natural waters. Environ Sci Technol 48:4573-4580

13. Deng J, Qin B, Paerl HW, Zhang Y, Wu P, Ma J, Chen Y (2014) Effect of nutrients, temperature and their interactions on spring phytoplankton community succession in Lake Taihu, China. PLoS ONE 9:e1271-e1275

14. Izaguirre I, Sanchez ML, Schiaffina MR, O'Farrell I, Huber P, Ferrer N, Zunino J, Lagomarsino L, Mancini M (2015) Which environmental factors trigger the dominance of phytoplankton species across a moisture gradient of shallow lake? Hydrobiologia 752:47-64

15. de Cardoso LS, Fragoso CR, Souza RS, da Marques DM (2012) Hydrodynamic control of plankton spatial and temporal heterogeneity in subtropical shallow lakes [M]. Hydrodyn Nat Water Bodies 67:268-285

16. Portalier SMJ, Cherif M, Zhang L, Fussmann GF, Loreau M (2016) Sizerelated effects of physical factors on phytoplankton communities. Ecol Model 323:41-50

17. Berger SA, Diehl S, Stibor H, Trommer G, Ruhenstroth M, Wild A et al (2007) Water temperature and mixing depth affect timing and magnitude of events during spring succession of the plankton. Oecologia 150(4):643-654

18. Jia Y, Chen W, Zuo Y, Lin L, Song L (2017) Heavy metal migration and risk transference associated with cyanobacterial blooms in eutrophic freshwater. Sci Total Environ 613:1324-1330

19. Miller RJ, Muller EB, Cole B, Martin T, Nisbet R et al (2017) Photosynthetic efficiency predicts toxic effects of metal nanomaterials in phytoplankton. Aquat Toxicol 183:85-93

20. Boyer JN, Kelble CR, Ortner PB, Rudnick DT (2009) Phytoplankton bloom status: chlorophyll a biomass as an indicator of water quality condition in the southern estuaries of Florida, USA. Ecol Ind 9S:S56-S57

21. Domis LN, Van DB, Helmsing NR, Van DE, Mooij WM (2016) Community stoichiometry in a changing world: combined effects of warming and eutrophication on phytoplankton dynamics. Ecology 95(6):1485-1495

22. O'Neil JM, Davis TW, Burford MA, Gobler CJ (2012) The rise of harmful cyanobacteria blooms: the potential roles of eutrophication and climate change. Harmful Algae 14:313-334

23. Steffen MM, Davis TW, Mckay RM, Bullerjahn GS, Krausfeldt LE et al (2017) Ecophysiological examination of the Lake Erie Microcystis bloom in 2014: linkages between biology and the water supply shutdown of Toledo, $\mathrm{OH}$. Environ Sci Technol. https://doi.org/10.1021/acs.est.7b00856

24. Rinehart KL, Namikoshi M, Choi BW (1994) Structure and biosynthesis of toxins from blue-green algae (cyanobacteria). J Appl Phycol 6(2):159-176

25. Nimptsch J, Woelfl S, Osorio S et al (2016) First record of toxins associated with cyanobacterial blooms in oligotrophic North Patagonian lakes of Chile-a genomic approach. Int Rev Hydrobiol 101(1-2):57-68

26. Izaguirre G, Jungblut AD, Neilan BA (2007) Benthic cyanobacteria (Oscillatoriaceae) that produce microcystin- $L R$, isolated from four reservoirs in southern California. Water Res 41(2):492-498

27. Nishiwaki-Matsushima R, Ohta T, Nishiwaki S, Suganuma M, Kohyama K et al (1992) Liver tumor promotion by the cyanobacterial cyclic peptide toxin microcystin-LR. J Cancer Res Clin Oncol 118:420-424

28. Gupta N, Pant SC, Vijayaraghavan R, Rao PVL (2003) Comparative toxicity evaluation of cyanobacterial cyclic peptide toxin microcystin variants ( $L R$, $\mathrm{RR}, \mathrm{YR}$ ) in mice. Toxicology 188:285-296

29. Gehringer MM (2004) Microcystin-LR and okadaic acid-induced cellular effects: a dualistic response. FEBS Lett 557:1-8 
30. Qin W, Xu L, Zhang X, Wang Y, Meng X, Miao A, Yang L (2010) Endoplasmic reticulum stress in murine liver and kidney exposed to microcystinLR. Toxicon 56:1334-1341

31. Zhao Y, Shi K, Su X, Xie L, Yan Y (2016) Microcystin-LR induces dysfunction of insulin secretion in rat insulinoma (INS-1) cells: implications for diabetes mellitus. J Hazard Mater 314:11-21

32. Li D, Erickson RA, Tang S, Zhang Y, Niu Z, Liu H, Yu H (2016) Structure and spatial patterns of macrobenthic community in Tai Lake, a large shallow lake, China. Ecol Ind 61:179-187

33. Duan H, Ma R, Xu X, Kong FX, Zhang SX, Kong WJ, Hao JY, Shang LL (2009) Two-decade reconstruction of algal blooms in China's Lake Taihu. Environ Sci Technol 43:3522-3528

34. Duan H, Loiselle SA, Zhu L, Feng L, Zhang Y, Ma R (2015) Distribution and incidence of algal blooms in Lake Taihu. Aquat Sci 77:9-16

35. Qin B, Xu P, Wu Q, Luo L, Zhang Y (2007) Environmental issues of LakeTaihu, China. Hydrobiologia 581:3-14

36. Paerl HW, Xu H, McCarthy MJ, Zhu G, Qin B, Li Y, Gardner WS (2011) Controlling harmful blooms of cyanobacteria in a hyper-eutrophic lake (Lake Taihu, China): the need for a dual nutrient (N \& P) management strategy. Water Res 45:1973-1983

37. Deng J, Qin B, Paerl HW, Zhang Y, Ma J, Chen Y (2014) Earlier and warme springs increase cyanobacterial (Microcystis spp.) blooms in subtropical Lake Taihu, China. Freshw Biol 59:1076-1085

38. Xu H, Paerl HW, Qin B, Zhu G, Hall NS, Wu Y (2015) Determining critical nutrient thresholds needed to control harmful blooms of cyanobacteria in eutrophic lake Taihu, China. Environ Sci Technol 49:1051-1059

39. Barrington DJ, Ghadouani A (2008) Application of hydrogen peroxide for the removal of toxic cyanobacteria and other phytoplankton from wastewater. Environ Sci Technol 42:8916-8921

40. Jiao Y, Chen Q, Chen X, Wang X, Liao X, Jiang L, Wu J, Yang L (2014) Occurrence and transfer of a cyanobacterial neurotoxin $\beta$-methylaminoL-alanine within the aquatic food webs of Gonghu Bay (Lake Taihu, China) to evaluate the potential human health risk. Sci Total Environ 468-469:457-463

41. Zhu M, Zhu G, Nurminen L, Wu T, Deng J, Zhang Y, Qin B, Ventela A (2015) The influence of macrophytes on sediment resuspension and the effect of associated nutrients in a shallow and large lake (Lake Taihu, China). PloS ONE. https://doi.org/10.1371/journal.pone.0127915

42. Xu X, Li W, Fujibayashi M, Nomura M, Nishimura O, Li X (2015) Asymmetric response of sedimentary pool to surface water in organics from a shallow hypereutrophic lake: the role of animal consumption and microbial utilization. Ecol Ind 58:346-355

43. State Environmental Protection Administration of China (2002) Water and wastewater monitoring analysis method. China Environmental Science Press, Beijing (in Chinese)

44. Rivasseau A, Racaud P, Deguin A et al (1999) Evaluation of an ELISA kit for the monitoring of microcystins (cyanobacterial toxins) in water and algae environmental samples. Environ Sci Technol 33:1520-1527

45. Jarkko R, Kirsti E, Jaana K, Kaarina S, Kirsti L (2002) Detection of microcys tins with protein phosphatase inhibition assay, high-performance liquid chromatography-UV detection and enzyme-linked immunosorbent assay comparison of methods. Anal Chim Acta 466:213-231

46. Zedeh LA (1965) Fuzzy sets. Inf Control 8:338-353

47. Don L (1994) Evaluating weapon system using fuzzy analysis hierarchy process based on entropy weight. Fuzzy Sets Systems 62:287-296

48. Qiu WH (2001) Management decision and applied entropy. China Machine Press, Beijing (in Chinese)

49. Hu HJ, Wei YX (2006) The freshwater algae of china systematics, taxonomy and ecology. The Science Publishing Company, Beijing (in Chinese)

50. Li X, Dreher TW, Li R (2016) An overview of diversity, occurrence, genetics and toxin production of bloom-forming Dolichospermum (Anabaena) species. Harmful Algae 54:54-68

51. Liu Y, Xu Y, Xiao P et al (2014) Genetic analysis on Dolichospermum (Cyanobacteria; sensu Anabaena) populations based on the cultureindependent clone libraries revealed the dominant genotypes existing in Lake Taihu, China. Harmful Algae 31:76-81

52. Yang M, Li X, Wang H, Zhang B (2016) Characteristic of summer microbenthic community in Adjacent sea of Yangtze River Estuary. Studia Marina Sinica 51:269-278

53. Rényi A (1961) On measures of entropy and information. Maximum Entropy Bayesian Methods Sci 1:547-561
54. Tóthmérész B (1998) On the characterization of scale-dependent diversity. Abstr Bot 22:149-156

55. Borics G, Gorgenyi J, Grigorszky I et al (2014) The role of phytoplankton diversity metrics in shallow lake and river quality assessment. Ecol Ind 45:28-36

56. Tang T, Wu N, Li F, Fu X, Cai Q (2013) Disentangling the roles of spatial and environmental variables in shaping benthic algal assemblages in rivers of central and northern China. Aquat Ecol 47:453-466

57. Lepš J, Šmilauer P (2003) Multivariate analysis of ecological data using CANOCO. Cambridge University Press, Cambridge

58. McGullagh P, Nelder JA (1989) Generalized linear models. Chapman \& Hall, London

59. Akaike H (1974) A new look at the statistical model identification. IEEE Trans Autom Control 19:716-723

60. Teittinen A, Kallajoki L, Meier S, Stigzelius T, Soininen J (2016) The roles of elevation and local environmental factors as drivers of diatom diversity in subarctic streams. Freshw Biol 61:1509-1521

61. Nanjing Institute of Geography \& Limnology (1965) Preliminary reports of comprehensive investigation on Taihu Lake. Science Press, Beijing (in Chinese)

62. Meng S, Chen J, Hu G, Zhai J, Wu W, Fan L, Ma X (2010) Annual dynamics of phytoplankton community in Meiliang Bay, Lake Taihu, 2008. J Lake Sci 22:577-584 (in Chinese)

63. Li S, Li H, Liang X, Chen Y, Cao Z, Xu Z (2009) Rural wastewater irrigation and nitrogen removal by the paddy wetland system in the Tai Lake region of China. J Soil Sediment 9:433-442

64. Qian K, Chen Y, Song X (2008) Long-term development of phytoplankton dominant species related to eutrophication in Lake Taihu. Ecol Sci 27:65-70 (in Chinese)

65. Borics G, Varbiro G, Tothmeresz B, Lukacs BA (2012) Functional groups of phytoplankton shaping diversity of shallow lake ecosystems. Hydrobiologia 698:251-262

66. Hegewald E, Padisak J, Friedl T (2007) Pseudotetraëdriella kamillae: taxonomy and ecology of a new member of the algal class Eustigmatophyceae (Stramenopiles). Hydrobiologia 586:107-116

67. Kumagai M, Nakano S, Jiao C, Hayakawa K, Tsujimura S, Nakajima T, Frenette J-J, Quesada A (2000) Effect of cyanobacterial blooms on thermal stratification. Limnology 1:191-195

68. Paerl HW, Otten TG (2013) Blooms bite the hand that feeds them. Science 342:433-434

69. Cardinale BJ, Hillebrand H, Harpole WS, Gross K, Ptacnik R (2009) Separating the influence of resource availability from resource imbalance on productivity-diversity relationships. Ecol Lett 12:475-487

70. Skacelova O, Leps J (2014) The relationship of diversity and biomass in phytoplankton communities weakens when accounting for species proportions. Hydrobiologia 724:67-77

71. Connell J (1978) Diversity in tropical rain forests and coral reefs. Science 199:1304-1310

72. Oliver RL, Ganf GG (2000) Freshwater bloom. In: Potts M (ed) The ecology of cyanobacteria. Kluwer Acdemic Publishers, Dordrecht, pp 149-194

73. Ooms MD, Cao TD, Sargent EH, Sinton D (2016) Photon management for augmented photosynthesis. Nat Commun 7:12699. https://doi. org/10.1038/ncomms12699

74. Dam BRV, Tobias C, Holbach A, Paerl HW, Zhu G (2018) $\mathrm{CO}_{2}$ limited conditions favor cyanobacteria in a hypereutrophic lake: an empirical and theoretical stable isotope study. Limnol Oceanogr. https://doi. org/10.1002/Ino.10798

75. Elliott JA, Jones ID, Thackeray SJ (2006) Testing the sensitivity of phytoplankton communities to changes in water temperature and nutrient load, in a temperate lake. Hydrobiologia 559:401-411

76. Bonilla S, Aubriot L, Soares MCS et al (2012) What drives the distribution of the bloom-forming cyanobacteria Planktothrix agardhii and Cylindrospermopsis raciborskii? FEMS Microbiol Ecol 79:594-607

77. Jouenne F, Lefebvre S, Veron B, Lagadeuc L (2007) Phytoplankton community structure and primary production in small intertidal estuarine-bay ecosystem (eastern English Channel France). Mar Biol 151:08-825

78. Jiang Y, He W, Liu W, Qin N, Ouyang H, Wang Q, Kong X, He Q, Yang C, Yang B, Xu F (2014) The seasonal and spatial variations of phytoplankton community and their correlation with environmental factors in a large eutrophic Chinese lake (Lake Chaohu). Ecol Ind 40:58-67 
79. Lv H, Yang J, Liu L, Yu X, Yu Z et al (2014) Temperature and nutrients are significant drivers of seasonal shift phytoplankton community from a drinking water reservoir, subtropical China. Environ Sci Pollut Res 21:5917-5928

80. Riekenberg J, Bargu S, Twilley R (2015) Phytoplankton community shifts and harmful algae presence in a diversion influenced estuary. Estuaries Coast 38:2213-2226

81. Cai LL, Zhu GW, Zhu MY, Xu H, Qin BQ et al (2012) Effects of temperature and nutrients on phytoplankton biomass during bloom seasons in Taihu Lake. Water Sci Eng 5:361-374

82. Liu X, Lu X, Chen Y (2011) The effects of temperature and nutrient ratios on Microcystis blooms in Lake Taihu, China: an 11-year investigation. Harmful Algae 10:337-343

83. Robarts RD, Zohary $T$ (1987) Temperature effects on photosynthetic capacity, respiration, and growth rates of bloom-forming cyanobacteria. N Z J Mar Freshw Res 21:391-399

84. Gala WR, Giesy JP (1991) Effects of ultraviolet radiation on the primary production of natural phytoplankton assemblages in Lake Michigan. Ecotoxicol Environ Saf 22:345-361

85. Qin J, Lehr CR, Yuan CG, Le XC, McDermott TR, Rosen BP (2009) Biotransformation of arsenic by a Yellowstone thermoacidophilic eukaryotic alga. Proc Natl Acad Sci USA 106:5213-5217

86. Caumette G, Koch I, House K, Reimer KL (2014) Arsenic cycling in freshwater phytoplankton and zooplankton cultures. Environ Chem 11:496-505

87. Yin X, Wang LH, Bai R, Huang H, Sun G (2012) Accumulation and transformation of arsenic in the blue-green alga Synechocysis sp. PCC6803. Water Air Soil Pollut 223:1183-1190

88. Zutshi S, Bano F, Ningthoujam M, Habib K, Fatma T (2014) Metabolic adaptations to arsenic-induced oxidative stress in Hapalosiphon fontinalis-339. IJIRSET 3:9386-9394
89. Kang R, Qin F, Wang J, Cao Shi D (2005) Effects of arsenic on growth and photosynthesis of cyanobacteria. Acta Hydrobiol Sin 29:230-232 (in Chinese)

90. Davis CC (1964) Evidence for the eutrophication of Lake Erie from phytoplankton records. Limnol Oceanogr 9:275-283

91. Tilman D, Kilham SS, Kilham P (1982) Phytoplankton community ecology: the role of limiting nutrients. Annu Rev Ecol Syst 13:349-372

92. Downing JA, Watson SB, McCauley E (2001) Predicting cyanobacteria dominance in lakes. Can J Fish Aquat Sci 58:1905-1908

93. Lehtinen S, Tamminen T, Ptacnik R, Andersen T (2017) Phytoplankton species richness, evenness, and production in relation to nutrient availability and imbalance. Limnol Oceanogr. https://doi.org/10.1002/Ino.10506

94. Keating KL (1978) Blue-green algal inhibition of diatom growth: transition from mesotrophic to eutrophic community structure. Science 199:971-973

95. Briand JF, Jacquet S, Bernard C, Humbert JF (2003) Health hazards for terrestrial vertebrates from toxic cyanobacteria in surface water ecosystems. Vet Res 34:361-377

96. Codd GA, Morrison LF, Metcalf JS (2005) Cyanobacterial toxins: risk management for health protection. Toxicol Appl Pharmacol 203:264-272

97. Herry E (2007) First observation of microcystins in Tunisian inland waters: a threat to river mouths and lagoon ecosystems. Transit Water Bull 2:73-82

98. Gan N, Xiao Y, Zhu L et al (2012) The role of microcystins in maintaining colonies of bloom-forming Microcystis spp. Environ Microbiol 14:730-742

99. Burkert U, Hyenstrand P, Drakare S et al (2001) Effects of the mixotrophic flagellate Ochromonas sp. on colony formation in Microcystis aeruginosa. Aquat Ecol 35:11-17

\section{Submit your manuscript to a SpringerOpen ${ }^{\circ}$ journal and benefit from:}

- Convenient online submission

- Rigorous peer review

- Open access: articles freely available online

- High visibility within the field

- Retaining the copyright to your article

Submit your next manuscript at $\mathbf{s p r i n g e r o p e n . c o m ~}$ 